\title{
EVALUATION AND STUDY PLAN THE FISHERMEN SETTLEMENT CASE STUDY: WURING VILLAGE, WEST ALOK DISTRICT, SIKKA REGENCY
}

\author{
Alexius Boer*1 \\ Architectural Engineering, Engineering Faculty, Nusa Nipa University ${ }^{1}$ \\ E-mail: *1alexius_boer@yahoo.com
}

\begin{abstract}
Abstrak. Desa nelayan merupakan desa yang mata pencaharian penduduknya adalah perikanan laut. Meningkatnya jumlah penduduk desa nelayan menyebabkan peningkatan kebutuhan hidup yaitu kebutuhan sandang, pangan, papan, pendidikan, dan kesehatan serta mengakibatkan kondisi kualitas lingkungan yang buruk. Penelitian ini bertujuan untuk mengevaluasi dan mengkaji kondisi pola spasial permukiman nelayan dan arahan penataan permukiman nelayan di Permukiman Wuring. Penelitian dilakukan dengan penelitian kualitatif. Tahap ini akan melakukan evaluasi dan penilaian kondisi spasial permukiman. Analisis data yang digunakan didasarkan pada skor dengan kriteria dan indikator yang telah ditentukan (Dirjen Cipta Karya, Kementerian Pekerjaan Umum, 2014 tentang Pedoman Pelaksanaan kegiatan identifikasi Kawasan Permukiman. Kumuh). Evaluasi kondisi permukiman nelayan di Perkampungan Wuring dapat dilihat dari nilai total keseluruhan komponen penilaian untuk Sembilan komponen penilaian. Hasil yang diperoleh adalah 2,88, artinya secara keseluruhan kualitas permukiman nelayan masih tergolong buruk karena di bawah angka 3. Arah pengembangan Perkampungan Wuring harus berdasarkan tata guna lahan. Pembagian zonasi kawasan permukiman nelayan Desa Wuring terdiri atas: Zona I, Perdagangan dan Jasa, Zona II, Pemanfaatan dan Zona III, Perlindungan. Kami menyimpulkan bahwa Desa Wuring dinilai buruk oleh karena itu mereka harus menata kembali kawasan tersebut menjadi zona tiga titik, Zona II dan Zona III.
\end{abstract}

Kata Kunci: Evaluasi; Penilaian; Pola Ruang; Perkampungan Wuring; Zona

\begin{abstract}
The increase in the fisherman village population causes an increase in the necessities of life, namely the need for clothing, food, shelter, education, and health, and leads to poor environmental quality conditions. This study aims to evaluate and assess the condition of the spatial pattern of fishermen settlements and the direction of arrangement of the fishermen settlement in Wuring Village. The research was conducted by qualitative research. This stage will carry out an evaluation and assessment of the spatial conditions of the settlement. The data analysis used is based on a score with predetermined criteria and indicators (DirjenCiptaKarya, Ministry of Public Work, 2014, concerning Guidelines for Implementation of Settlement Area identification activities. Grungy). Evaluation of the condition of the fishermen settlement in Wuring village can be seen from the total value of the overall assessment components for the 9 assessment components. The result obtained is 2.88, meaning that the overall quality of the fishermen settlement is still considered poor because it is below number 3. The zoning division in the fishing settlement area of Wuring village consists of: Zone I, Trade and services, Zone-II, Utilization, and Zone III, Protection. We conclude that Wuring Village assed as a bad point therefore they should rearrange the area to be three-point Zone I, Zone II, and Zone III.
\end{abstract}

Keywords: Evaluation; Assessment; Spatial Pattern; Wuring Village; Zone

\footnotetext{
${ }^{1}$ Architectural Engineering, Engineering Faculty, Nusa Nipa University
} 


\section{INTRODUCTION}

According to the Regulation of the Ministry of Public Housing of the Republic of Indonesia Number 15/Permen/M/2006 concerning Implementation Guidelines for the Development of Fishery Areas, fisherman area settlements, to support marine and fishery function activities. Fisherman settlement is a place where the livelihood of its residents is marine fisheries (Raharjo 2014). The increase in Fisherman settlement population causes an increase in the necessities of life, namely the need for clothing, food, shelter, education, and health (Hariyono 2010). Settlement problems include non-physical issues between social, economic, cultural, ecological and physical environmental problems including infrastructure and housing facilities (Nafsi et al. 2019; Ruli and Siti 2018; Wiarni, Mononimbar, and Supardjo 2018).

One indication of the decline in settlement quality is by looking at the physical and nonphysical conditions of the settlement environment. The Fisherman settlement of Wuring, which grows and develops naturally with poor environmental quality conditions, can affect the life patterns of the local community. Settlement problems that occur include the inadequate physical condition of the house and inadequate supply of infrastructure and facilities and poorly planned spatial planning. Environmental damage can also occur due to settlement development patterns that are not well organized and are thought to exceed the carrying capacity of the environment, such as density, size, layout of buildings and forms of settlement as well as inadequate conditions of infrastructure and settlement facilities. The improvement of Fisherman settlement is carried out in an effort to maintain the quality of the coastal area environment and to improve the quality of the coastal settlement environment (Surtiani 2006). This study aims to evaluate and assess the condition of the spatial pattern and the direction of arrangement of the fishermen settlement in Wuring Village.

\section{METODE}

The research was conducted in the traditional fishing settlement area of Wuring Village, Wolomarang Sub-Districtis located in West Alok District, Sikka Regency, in the East Nusa Tenggara Province. The first step is evaluation and assessment of the spatial conditions of the settlement. Descriptive analysis was used to analyze the conditions of the fishing settlement of Wuring village. Analysis of the physical quality of residential spatial planning is done by conducting an assessment based on the weighted value according to the predetermined criteria and indicators. Furthermore, an evaluation was carried out based on the assessment criteria and then the value/score for each component was determined according to the spatial pattern based on a score with predetermined criteria and indicators (Dirjen Cipta Karya, Ministry of Public Works, 2014, concerning Guidelines for Implementation of Settlement Area identification activities Fishery Areas).

Analysis of the direction of spatial planning in the fishing settlement of Wuring village was carried out, namely by knowing the existing problems from the identification results, including the residential conditions of the Wuring fishermen settlement, the conditions of infrastructure, as well as the social and cultural economic conditions of the population as well as knowing the potential of the Wuring fishermen settlement and literature study to determine the most appropriate pattern in regional development. 


\section{RESULT AND DISCUSSION}

\section{A. Evaluation and Assessment of the Condition of the Spatial Pattern of Fishermen's Settlement in Wuring Village}

Spatial planning is a form of spatial structure and pattern which includes the arrangement of settlement centers and systems of infrastructure and facilities. It functions as a support for the socio-economic activities of the community which hierarchically have functional and interrelated relationships to form a spatial pattern in a settlement (Law No. 26/2007). The score of all components are grouped into five assessment categories, namely very good, good, moderate, bad, and very bad. The results of research related to settlement quality can be seen in Table 1 .

Table 1. The results of the assessment of the condition of the fishermen settlement of Wuring village

\begin{tabular}{|c|c|c|c|c|}
\hline No & $\begin{array}{c}\text { Assessment } \\
\text { Component }\end{array}$ & Score & $\begin{array}{l}\text { Settlement } \\
\text { Condition }\end{array}$ & Criteria Description \\
\hline 1 & Building density & 2 & Bad & $\begin{array}{l}\text { Floor area of the number of residents is less than } 9 \\
\mathrm{~m}^{2} / \text { person, the distance between houses is close } \\
\text { to each other and disturbs vehicle and human } \\
\text { traffic activities }\end{array}$ \\
\hline 2 & Road Network & 2 & Bad & $\begin{array}{l}\text { asphalt, paving, soil, bamboo, lots, poor condition } \\
\text { bridges, potholes roads }\end{array}$ \\
\hline 3 & Drainage Network & 2 & Bad & $\begin{array}{l}\text { no drainage channels, stagnant water, lots of } \\
\text { garbage }\end{array}$ \\
\hline 4 & Garbage Processing & 2 & Bad & $\begin{array}{l}\text { there is no place for container garbage, burned, } \\
\text { dumped into the sea }\end{array}$ \\
\hline 5 & Sanitation & 2 & Bad & $\begin{array}{l}\text { Private WC but not available septic tank and } \\
\text { infiltration and but dumped into the sea }\end{array}$ \\
\hline 6 & $\begin{array}{l}\text { Building area / } \\
\text { feasibility }\end{array}$ & 3 & Moderate & $\begin{array}{l}\text { residential buildings have a floor area of less than } \\
36 \mathrm{~m} 2,5 \text { inhabitants of the house, zinc / tile roofs, } \\
\text { planks / bamboo walls, }\end{array}$ \\
\hline 7 & $\begin{array}{l}\text { Regularity / } \\
\text { orientation of the } \\
\text { building }\end{array}$ & 3 & Moderate & $\begin{array}{l}\text { buildings facing the road, the shape of the building } \\
\text { is not the same, the size of the land is not the same, } \\
\text { the building does not face the sea }\end{array}$ \\
\hline 8 & $\begin{array}{l}\text { Drinking Water } \\
\text { system }\end{array}$ & 5 & Very Good & $\begin{array}{l}\text { clean source of PDAM available private pipeline } \\
\text { network, public pipeline network) }\end{array}$ \\
\hline 9 & Electric network & 5 & Very Good & There is PLN network, private electric \\
\hline & Average & 26 & & 2,88; Bad \\
\hline
\end{tabular}

Source: Analysis Results, 2019

Evaluation of the condition of the fishermen settlement in Wuring village can be seen from the total value of the overall assessment components for the 9 assessment components. The result obtained is 2.88, meaning that the overall quality of the fishermen settlement is still considered poor because it is number 2 This is because there are several residential components that are more dominant showing bad conditions are as follows: building arrangement and layout, non-standard/narrow building sizes, inadequate drainage systems, sanitation, and waste management. The flow of sea water is also one of the reasons for the low quality of settlements, because the garbage carried at high tide will pollute the neighborhood, the condition of the buildings is very dense and the area of residential buildings is not balanced with the number of people in one house. The value of waste management shows the value in a bad category with number 2 with a description of where the waste is stored, burned, disposed of at sea. Increasing the concept of zero waste is the most important thing in implementation, which can be started from individuals/households, local scale to city scale. The garbage disposal system in this area is provided by placing several temporary garbage dumps in each 
residential zone. Waste management on an environmental scale with the Reduce, Reuse, Recycle (3R) approach to reduce waste production from the source (Susanto 2016).

\section{B. Direction of Arrangement of Wuring Village Fishermen's Settlement}

Increasing the concentration of the residential environment is often not followed by an increase in settlement infrastructure and facilities (Himan, Syarif, and Rahim 2018). Spatial planning is the result of spatial planning in the form of policy direction and allocation of spatial use which structurally describe as the integrated location function ties of various community life activities (Law No. 26 of 2007). Based on this, the direction of the arrangement of the spatial pattern of traditional fishing settlement of Wuring village, it is stated in the Regional Regulation of Sikka Regency Number 2 of 2012 the traditional fishing settlement of Wuring in Wolomarang sub-district is actually more intended as a cultural tourism area / traditional village.

Wuring settlement is one of the tourist destinations in Sikka Regency. The exoticism of the Wuring settlement can be seen from the traditional settlements and the majority of the people who work as fishermen who build their houses on the sea, with wooden poles 2-3 meters high and use walls of bamboo slats or wooden boards. This means that the traditional fishing of Wuring should only be used as a tourist place and not as a permanent residence for fishermen. This is reinforced by the results of a survey on the condition of infrastructure in the fishing settlement of Wuring settlement which is limited. Research by Ristianti (2015) explains that the arrangement of fishing village areas on the coast of Balikpapan really requires an approach in the form of a smart eco-village, namely the arrangement of areas that utilize coastal ecology in the provision of fishing settlement areas. The arrangement of this area also includes adequate infrastructure. The residents' access to the use of facilities and infrastructure is also very limited.

The fishing settlement of Wuring village does not have any supporting infrastructure for settlements such as healthy sanitation infrastructure, temporary garbage dumps and drainage. In other words, the traditional fishing village of Wuring is not suitable to be developed as a permanent settlement or residence. The implementation of zone must fulfill several principles, namely, improving the economic and social quality of residents by providing infrastructure for integrated economic and social functions, improving the quality of environmental comfort, green open space and non-green open space integrated with increase in the quality of the components of the slum. The arrangement of the Wuring is directed at eliminating slums by creating a more humane, livable and well-ordered settlement.

The direction for the development of the fishermen settlement can be done by looking at the conditions and the results of the assessment are as follows:

1. Controlling and improving the quality of buildings on the growth of fishing settlement areas, arranging and repairing environmental facilities and infrastructure, repairing existing buildings while maintaining the existing culture and traditional buildings, conducting special supervision and control in the development and construction of houses through permit from the government

2. A Detailed spatial plan is needed to the area of traditional fishing settlements in Wuring in order to make it a traditional tourism in Sikka Regency.

3. Creating a zoning plan for the development of the fishermen settlement area in order to organize the settlement of the fishermen in Writing as a cultural to urism site. 
Table 2. Zoning Plan for Wuring Settlement

\begin{tabular}{lll}
\multicolumn{1}{c}{ No Zone Plan } & \multicolumn{1}{c}{ Development Goals and Directions } \\
\hline 1 & Zone I, Trade and services & Preparing land for trade and services: \\
& 1) Port \\
& 2) Sub Port \\
& 3) Boat mooring \\
& 4) TPI \\
5) Fish drying place & 6) Traditional markets \\
& 7) Shop \\
& 8) Port terminals and supporting facilities \\
& 9) Hotel / lodging \\
& 10) Restaurant \\
\hline 2 & Providing land for residential development of traditional Bajo housing \\
& settlements: \\
& Creating policies regarding the requirements for making houses in fishing \\
& settlement areas (traditional houses of the Bajo tribe) \\
\hline 3 & Preparing place for sightseeing as well as the preservation and protection of \\
& residential areas \\
& 1) Cultural tourism \\
& 2) Culinary tourism of seafood \\
& 3) Marine tourism \\
& 4) Setting up a green open space \\
& 5) Preservation of mangrove forests
\end{tabular}

Source: Analysis Results, 2019

The zoning division in the fishing settlement in Writing consists of:

1. Zone I, Trade and services

The core zone becomes the center of activity and movement in the Wuring settlement, this is because there are facilities that can support activities in the Wuring settlement. This zone functions as a center for business activities, shopping centers, buildings, banks and markets, passenger ports, boat moorings, docks.

2. Zone II, Utilization

In the utilization zone the fishermen settlement a is designated. This zone is in a land area while maintaining the traditions or culture of the Bajo tribe and reducing the risk of sea tides. In this concept, land use will be determined in accordance with the function, ease of circulation, and the waste management system. Broadly speaking, the land use concept applied in this area planning program is divided into 4 major function zones, namely commercial zones, residential zones and green open space zones (Susanto 2016).

3. Zone III, Protection

In this zone it is more intended as a protection area. This zone generally consists of oceans. The purpose of the zone is as a conservation and conservation area for waters and can be used for various activities such as business, marine tourism, cultural tourism (Bajo tribe floating houses) and economic empowerment of other communities. The natural panorama in the sea around the Wuring settlement in the form of ecosystems and marine life can be a capital in tourism development. Green open space planning in the fishing settlement is divided into two types, namely green belt planning and green park (square)(Susanto 2016). Zoning distribution and development direction in the fishing settlement as shown in Table 2. 
The zoning division of the Wuring areas can be seen in Figure 1.

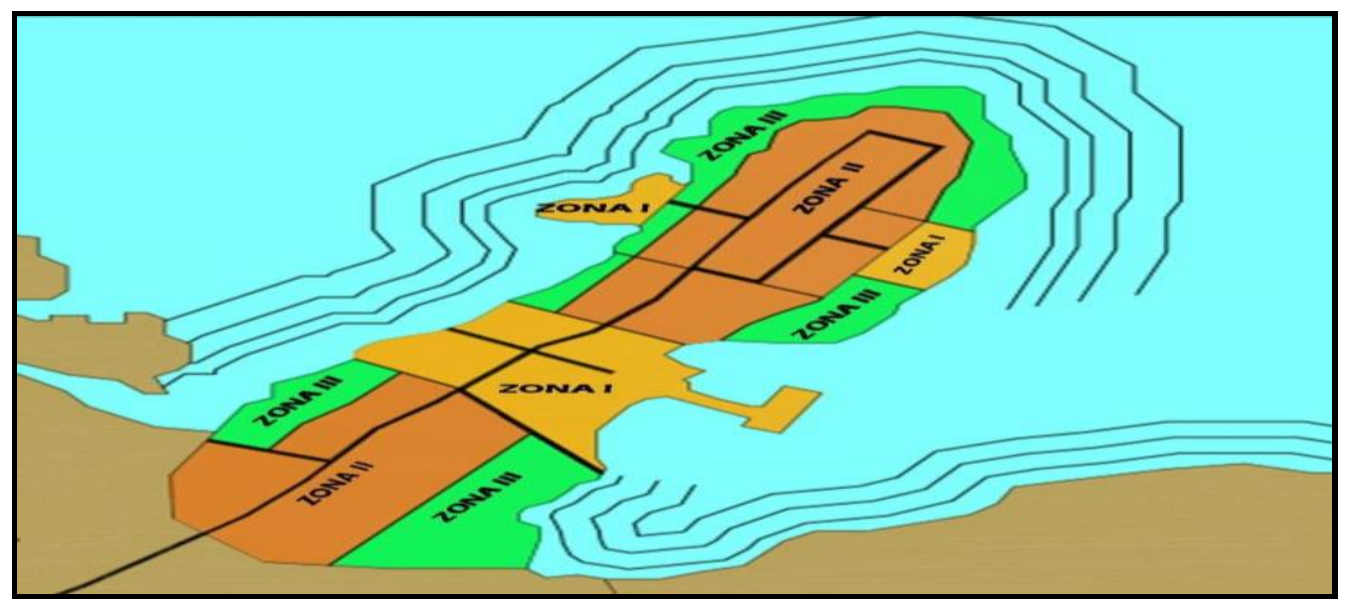

Figure 1. Zoning of the Fishermen Settlement of The Wuring Village Source: Analysis Results, 2019

According to the Department of Settlements and Regional Infrastructure of the Directorate General of Housing and Settlements in 2002 are required as follows:

1. The shape and size of the block is based on the efficiency and effectiveness of land use. The shape of the building block is determined by a rectangular modification. Meanwhile, the block size is determined by considering the length of the small type building block with a maximum of 60 meters in front of the alley (10 housing units with a spot width of 6 meters or 12 units with a width spot $5 \mathrm{~m}$ ).

2. Block grouping and configuration are determined based on the consideration of the effectiveness and efficiency of land use and road infrastructure patterns, the effectiveness and efficiency of the implementation of daily activities and the form of land in the area.

3. The placement of the tourist area is regulated by the water depth between 0-10 m, taking into account the carrying capacity of the area and the capacity of the visitors.

4. Easy access to land and water road networks, if there is communal space for a number of households, then the orientation of the building can be facing the communal space or behind the communal space. Easy access must be considered for fishing activities as well as taking advantage of the potential of the water scene.

5. The figure of the building mass is designed to follow livable and healthy building regulations, non-tiered building construction regulations, earthquake, flood and tsunami resistant regulations, while the architectural expression of the building for tidal housing accentuates the traditional architectural identity of the house on stilts and its closeness to service activities, reflects the character of simplicity in the use of materials and robustness against the power of water and wind.

From the non-architectural aspect, this arrangement is a form of responsiveness to the area's needs for facilities that can play an active role in the development of the port area so that it has a positive impact on the socio-economic activities of the area and its residents, by carry out supporting functions such as restaurants, drying areas, packing areas, as well as a gift shop (Fachrudin and Rahmadani 2019). 


\section{CONCLUSION}

In conclusion, we evaluated and assessed the Wuring settlement that the total value of the overall assessment components for the nine assessment components leads to 2.88. The score mean quality of the fishermen settlement is still considered bad because it is below number three. To plan those areas to become better places. The community should divide three zone that includes all the area. The zoning division in the Wuring area consists of: Zone I, Trade and services, Zone II, Utilization and Zone III, Protection.

\section{REFERENCE}

Fachrudin, Hilma Tamiami, and Fadila Rahmadani. 2019. "Penataan Kampung Nelayan Dengan Pendekatan Arsitektur Ekologi di Kelurahan Bagan Deli Kota Medan.” Jurnal Arsitektur ARCADE 3(2): 148-52.

Hariyono, Paulus. 2010. Perencanaan Pembangunan Kota dan Perubahan Paradigma. Yogyakarta: Pustaka Pelajar.

Himan, Muhammad, Muh Syarif, and Manat Rahim. 2018. "Analisis Ketersediaan Prasarana Dan Sarana Permukiman Nelayan Di Kelurahan Lakologou Kecamatan Kokalukuna Kota Baubau.” Jurnal Perencanaan wilayah 3(2): 1-15.

Nafsi, Nur, Siti Belinda, Santi, and Aspin. 2019. “Karakteristik Permukiman Kumuh.” 1(1): 30-39.

Raharjo. 2014. Pengantar Sosiologi Pedesaan Dan Pertanian. Yogyakarta: Gadjah Mada University Press.

Ristianti, Novia Sari. 2015. "Pengembangan Konsep Wisata Apung Kampung Nelayan Pesisir Balikpapan." Ruang 1(1): 31-40.

Ruli, As'ari, and Fadjarani Siti. 2018. “Penataan Permukiman Kumuh Berbasis Lingkungan.” 15(1): 56-67.

Surtiani, Eny endang. 2006. "Faktor-Faktor Yang Mempengaruhi Terciptanya Kawasan Permukiman Kumuh Di Kawasan Pusat Kota (Studi Kasus : Kawasan Pancuran, Salatiga).” Universitas Diponegoro.

Susanto, Roswita Rensa. 2016. "Penataan Permukiman Nelayan Menuju Kawasan Zero Waste." ARTEKS, Jurnal Teknik Arsitektur 1(1): 83-98.

Wiarni, Suci, Windy Mononimbar, and Suryadi Supardjo. 2018. "Analisis Tingkat Kekumuhan Kawasan Permukiman di Kecamatan Kotamobagu Timur.” Jurnal Perencanaan Wilayah dan Kota 5(1): 61-70. 